\title{
Angels or Aliens? Refugee Nurses in Britain, 1938 to 1942
}

\author{
JOHN STEWART*
}

In spring 1940 Annie Altschul, an Austrian probationer nurse at Ealing Voluntary Hospital in London, was forced to leave her employment. Altschul was later to become a pioneer in psychiatric nursing and in 1976 was appointed Professor of Nursing at Edinburgh University, the first from her specialism to attain this rank. In 1940, however, Altschul, a socialist and former Viennese mathematics student, was a refugee from fascist and Nazi oppression in her homeland. ${ }^{1}$ Her exile status and political standpoint notwithstanding, she, like other nurses driven from their own countries, found herself in a situation where the question of whether or not she could be employed in British health care depended on a complex nexus of regulations, nationality, and the currently prevailing political and military circumstances. This article examines policy towards, and the experience of, refugee nurses in Britain from the late-1930s, when the refugee problem became particularly serious, to around 1942 , by which time restrictions on the employment of "aliens" had considerably relaxed, the threat of invasion had receded, and an Allied victory seemed increasingly likely.

\section{Evidence and Aims}

There is now an extensive historiography on refugees to Britain in the 1930s and 1940 s. $^{2}$ However, the historiography of refugee women remains relatively weak and that of nurses weaker still, the latter especially when compared with the work done

* John Stewart, BA, MPhil, FRHistS, Department of History, Tonge Building, Oxford Brookes University, Oxford OX3 0BP; jwstewart@brookes.ac.uk.

An early version of this paper was given at the 'Cinderella Services' conference, South Bank University, London, April 2001. I am grateful for the comments it elicited, which included personal recollections of refugee nurses. I would also like to thank the archivists of the University of Southampton; the Public Record Office; the London Metropolitan Archives; the University of Edinburgh Special Collections Department; and, in particular, Dr Susan McGann at the Royal College of Nursing. The Wellcome Trust has supported my research on the Socialist Medical Association. Dr Steven King, who read an earlier draft, Dr Stephanie Kirby, and Professor Paul
Weindling have all been supportive of this aspect of my work. This journal's anonymous referees provided constructive comments on an earlier draft.

${ }^{1}$ Peter Nolan, 'Annie Altschul's legacy to 20th century British mental health nursing', $J$.

Psychiatr. ment. Health Nurs., 1999, 6: 262-72. I am grateful to Professor Nolan for bringing his article to my attention. See also Altschul's obituary, Guardian, 8 Jan. 2002, p.18.

${ }^{2}$ Among the most important works are: Louise London, Whitehall and the Jews, 1933-1948, Cambridge University Press, 2000; A J Sherman, Island refuge: Britain and refugees from the Third Reich, 1933-1939, 2nd ed., Ilford, Frank Cass, 1994; Gerhard Hirschfeld (ed.), Exile in Great Britain, Leamington Spa, Berg for the German Historical Institute, 1984. 


\section{John Stewart}

on doctors and medical scientists. Nor is this an indicator of insignificant numbers of refugee nurses, of whom by the early part of the war there were well over $1,000{ }^{3}$ Of course there are problems with sources on both refugees in general and nurses in particular. The papers of the refugee organizations are incomplete and those of nursing bodies such as the General Nursing Council (GNC) and the Royal College of Nursing (RCN) are largely, although not entirely, silent on the subject. Direct evidence from the refugees themselves is also problematic, although once again not entirely absent. None the less, material can be found in professional journals such as the Nursing Times and the Nursing Mirror; the files of government ministries; local authority records; the papers of those refugee organizations which have been preserved; the administrative records of individual hospitals, a rich source which deserves further exploration; personal recollections; and the archives of sympathetic organizations such as the Labour Party affiliated group of left-wing doctors and nurses, the Socialist Medical Association (SMA). ${ }^{4}$ This article is therefore a first step towards a fuller understanding of a previously neglected historical episode, illuminated by the idea that "nursing history cannot be understood in its own terms" but rather that it must be analysed in the context of the "social, political, economic and cultural context in which it subsists". ${ }^{5}$ At the same time, it is further suggested that these contexts are themselves enriched by an understanding of the position of nurses within them.

As will become apparent, two issues emerge as especially noteworthy: first, the complexity of the government regulations determining where, or if at all, refugee nurses might be employed. For those who had fled fascist oppression and sought to aid the British war effort this must have been, to say the least, personally distressing particularly when combined, as in summer 1940, with anti-foreigner sentiment. There were also employment constraints in that foreign qualifications were not generally recognized. Fully qualified refugee nurses therefore had to undertake British training or work as assistant nurses. On both these counts it can be argued that at least in the early part of the war the British hospital system was deprived of much needed nursing skills. Second, and more positively, refugees were on occasions praised for their commitment, supported by the hospitals in which they worked, and looked on as one way of alleviating the widely-acknowledged nursing shortage of the late 1930s, a situation further exacerbated by the outbreak of war. In contrast to the allegedly "overstocked" medical profession, nurses and trainee nurses were in short supply. As the Chief Medical Officer for London told the London County Council (LCC)

\footnotetext{
${ }^{3}$ Sibylle Quack, 'Introduction', in Sibylle Quack (ed.), Between sorrow and strength: women refugees of the Nazi period, Washington, DC, German Historical Institute; Cambridge University Press, 1995, pp. 1-10, on p.1; and Jill Davidson, 'German Jewish women in England', in W E Mosse (ed.), Second chance: two centuries of German-speaking Jews in the United Kingdom, Tubingen, J C B Mohr, 1991, pp. 533-52. Interestingly, neither of these essays mentions nurses. On doctors and medical scientists, see, for example, Paul Weindling, 'The contribution of
}

central European Jews to medical science and practice in Britain, 1930s-1950s', in ibid., pp. 243-54.

${ }^{4}$ On the SMA, see John Stewart, 'The battle for health': a political history of the Socialist Medical Association, 1930-1951, Aldershot, Ashgate, 1999. Ch. 6 of this work deals with the organization's attitude to refugees.

s'Introduction', in A M Rafferty, Jane Robinson and Ruth Elkan (eds), Nursing history and the politics of welfare, London, Routledge, 1997, pp. 1-9, on p. 4. 
leader, Herbert Morrison, in 1937, the shortage of recruits to nursing was not a new problem but none the less "recently it has become more acute owing to some extent to the large increase required in the number of the Council's nursing staff". As is well known, labour market issues contributed to the notorious hostility of organizations such as the British Medical Association to the employment, or even admission, of refugee doctors. The case of nursing was clearly rather different, at least by the late 1930s. It has been remarked that recruitment crises and acute shortages of nursing labour have been "notorious catalysts for reform programmes in nursing", and the case of the treatment of refugee nurses might be seen as a variant on this theme. ${ }^{6}$ Before examining these issues further, however, it is necessary to outline the background to the refugee situation.

\section{Refugees, Refugee Nurses, and Refugee Nurse Organizations}

Refugees from Germany began to arrive from the early 1930s and it is estimated that between 1933 and the outbreak of war in 1939 more than 50,000 Germans, Austrians and Czechoslovakians entered the country. ${ }^{7}$ Particular pressure points were the coming to power of the Nazis in Germany in 1933; the emergence of a quasi-fascist regime in Austria in 1934; the Austrian Anschluss-that is occupation by Germany - of March 1938; the German annexation of the Sudetenland in October 1938; and the Kristallnacht - a particularly barbaric outburst of public anti-semitism in Germany-in November 1938. The pre-war refugee situation became especially acute as a result of the cumulative events of 1938, as was recognized in the Evian conference of July that year. Refugees also came from other countries and situations: among refugee nurses could be found, for example, Italian opponents of Mussolini's fascist regime and those fleeing Poland and Norway after their invasion by Germany in, respectively, September 1939 and April 1940. The outcome of the Spanish Civil War too saw anti-fascists urgently seeking shelter and support elsewhere. The SMA raised funds to bring some fifteen nurses and doctors out of Spain to Britain, from where they went on to China - another area of political conflict in this period-to work with the Red Cross. ${ }^{8}$ All this reminds us of the highly unstable nature of the world of the 1930s, which both created its own refugee situations and exacerbated population displacements created by the First World War and its aftermath.

In Britain itself there was a grudging acceptance of a limited number of refugees. Attitudes, popular and official, were in part shaped by concerns over the impact of foreigners on the labour market in an era of high and persistent unemployment. Prior to the events of 1938, entry into Britain was highly constrained and the United States and European countries such as France received the bulk of those fleeing

\footnotetext{
${ }^{6}$ London Metropolitan Archives (hereafter LMA) LCC/PH/STA/1/7, memorandum from Medical Officer of Health to Herbert Morrison, May 1937; 'Introduction', in Rafferty, Robinson and Elkan (eds), op. cit., note 5 above, p. 7.

${ }^{7} \mathrm{~A}$ lower figure is given in F L Carsten,

'German refugees in Great Britain 1933-1945', in Hirschfeld (ed.), op. cit., note 2 above, pp. 11-28,
}

on p.15; a rather higher estimate is given by Sherman, op. cit., note 2 above, p. 7.

${ }^{8}$ University of Hull, Brynmor Jones Library, Socialist Medical Association Archive (hereafter DSM), DSM/1/1, Report of the Executive Committee, 1938/9; Report of the Executive Committee, May 1939-April 1940. 


\section{John Stewart}

Nazi Germany. ${ }^{9}$ Discussing the particular circumstances of nurses, a Ministry of Labour official noted that up until 1938 it was his Department which was responsible for issuing work permits and that it had operated a "definite restrictive policy". So permits would not be granted to aliens simply to make good shortages in British hospitals; the number of foreigners per hospital was limited to 3 per cent of staff; and it was a condition of training that after qualification such nurses would either have to go back to their own countries or, in the case of Germans, emigrate. As he further put it,

[the] fact that only 215 nurses of all nationalities were allowed by us to take hospital work either as probationers or post-graduates during the years 1935 to 1937 indicates that a fairly restrictive policy operated in regard to the engagement of foreign nurses [emphasis in original]. ${ }^{10}$

This can be contrasted with the 20,000 pre-war refugees who were employed as domestic servants. ${ }^{11}$

From 1938 it remained the case that entry to Britain was by no means easy, but at least in certain respects a rather more liberal official policy was adopted during the remaining months of peace. This, when combined with a sense that the Home Office was not always entirely in control of affairs, ${ }^{12}$ eased the circumstances of most categories of refugee. With the coming of war in 1939 the situation became, once again, problematic. Any plans for re-emigration had to be immediately shelved. ${ }^{13}$ Certain refugees were classified as "enemy" aliens: Austrians and Germans initially, Italians when their country entered the war, and, briefly, Czechoslovakians. Those from countries such as Poland were deemed "friendly" aliens, that is originally from a nation now allied to Britain; while others still were "neutral" aliens. Enemy aliens were required to appear before tribunals set up to judge whether they really were victims of Nazi oppression and if so how to deal with them. Anti-foreigner sentiment became particularly pronounced in summer 1940, after defeat in Scandinavia and France, and large numbers of enemy aliens were interned. A few months later, however, public sentiment once again shifted to being pro-refugee, and those interned were gradually released. ${ }^{14}$ By 1942 the situation had considerably eased, not least because the demands of the wartime economy meant that arguments about refugees taking British jobs no longer held. Indeed, such were the problems of having adequate levels of nursing staff in the difficult circumstances of the early war years that, for example, the LCC noted a decrease in its total nursing staff of around 10 per cent between the outbreak of war and early 1941. This was in part due to the difficulties now experienced in recruiting student nurses from local schools, which had been evacuated, and from Ireland, an important source for the LCC. ${ }^{15}$

\footnotetext{
${ }^{9}$ Gerhard Hirschfeld, 'Introduction', in Hirschfeld (ed.), op. cit., note 2 above, p. 2.

${ }^{10}$ Public Record Office, Kew (hereafter PRO) LAB 8/93, memorandum of 2 Sept. 1940.

${ }^{11}$ Davidson, op. cit., note 3 above, p. 539.

${ }^{12}$ Sherman, op. cit., note 2 above, p. 7.

${ }^{13}$ François Lafitte, The internment of aliens, Harmondsworth, Penguin, 1940, p. 50.
}

\footnotetext{
${ }^{14}$ Carsten, op. cit., note 7 above, pp. 21-8.

${ }^{15}$ LMA LCC/PH/STA/1/8, memorandum of 15 Jan. 1941. Pre-war some 11,700 nurses had been employed by the Public Health Department, and by January 1941 this had fallen by around 1,200. S A Kirby, 'The London County Council Nursing Service, 1929-1948', unpublished University of Nottingham PhD thesis, 2001.
} 
The refugee situation was a complex one with which a number of bodies, official and otherwise, were involved. ${ }^{16}$ At governmental level various ministries took an interest and, especially in summer 1940 when enemy aliens were dismissed from employment, the relationships between them led to complicated and sometimes contradictory regulations. Refugee nurses dealt with, at various points, the Home Office and its Aliens Department, and the Ministry of Health, which was responsible for the dismissal of refugee medical staff in 1940 and whose Central Emergency Committee for the Nursing Profession (CECNP) grappled, inter alia, with the vexed question of how much, if any, contact refugee nurses might have with injured forces personnel.

The Ministry of Labour too had a long involvement with refugee employment, and during the war operated through the associated Aliens War Service Department and its International Labour Branch, the latter having a section dedicated to nursing. As we have seen, the Ministry prior to 1938 sought to operate a restrictive attitude. However, the point made by Louise London is also worth noting. The Ministry of Labour, she observes, did indeed have a stated policy of "severe restriction and a stern public stance". Nevertheless, it was also prepared to "bend the rules to let certain refugees take employment" and among these were trainee nurses. ${ }^{17}$ So, for example, in late 1933 the College of Nursing wrote to the Ministry on the employment of refugees as nurses. "We are constantly hearing", the letter claimed, "of Jewish refugees from Germany wishing to train in this country as nurses". There was no desire to "add to the already great difficulties confronting these women", but none the less the College was strongly opposed to such facilities being offered, precisely on the grounds that when trained these nurses would compete with British nurses. This would make a "grave" situation "even graver". This was an analysis with which Ministry officials disagreed, citing research by the Lancet and arguing that numbers would be negligible and no hospital would be under any compulsion to accept refugee probationers. ${ }^{18}$ We thus find here, first, the rather more relaxed private attitude noted by London; and, second, a willingness on the part of Ministry of Labour officials to be more dismissive of the arguments of the nursing profession than they were later to be of the medical profession when the latter sought, successfully, to restrict the number of refugee medical practitioners.

At a local level we shall see how individual hospital authorities responded to the challenge of the refugee issue. One particularly important local authority was the LCC, at this point the largest single provider of hospital beds in Britain and thus a major employer of nursing staff both in its hospitals and in other appropriate situations. It was controlled from 1934 by the Labour Party and, crucially, from that point its important Hospital and Medical Services Committee was dominated by the SMA. Given the size of the LCC and the SMA's pro-refugee attitude, this was potentially a useful avenue for exiled nurses to pursue. ${ }^{19}$ So, for example, in

\footnotetext{
${ }^{16}$ See London, op. cit., note 2 above, for the roles of the various ministries.

${ }^{17}$ London, op. cit., note 2 above, pp. 46-7.

${ }^{18}$ PRO MH 55/447, letter from the College of Nursing to the Ministry of Labour, 22 Nov. 1933,
}

and subsequent memoranda. I am grateful to Dr Stephanie Kirby for this reference.

${ }^{19}$ For the SMA's role on the LCC, see

Stewart, op. cit., note 4 above, ch. 5 . 


\section{John Stewart}

August and September 1937 correspondence took place between Ewald Fabian, leader of the International Socialist Medical Association, and one of his British counterparts, the London general practitioner, Charles Brook. Fabian sought Brook's advice as to whether the latter could find employment for a nurse, with two German diplomas, who wished to leave Berlin. Brook, who was not only an SMA founding member but also a London County Councillor, replied that women of other than British nationality could be taken on by the LCC Hospital Service; that there was a great shortage of nurses; that, in consequence, any refugee with good qualifications and a knowledge of English would get a post; and that the individual concerned should thus write to the council's Matron in Chief mentioning his name or that of his SMA colleague and Chairman of the Hospital and Medical Services Committee, Somerville Hastings, should she so wish. ${ }^{20}$ As we shall see, Brook was wrong to claim, at this point, that non-Britons could be so employed by the LCC. But his confidence suggests that social and political networks may have circumvented official regulations, regulations which were in principle if not necessarily in practice strict, at a time when individual hospitals and hospital authorities had a large measure of discretion over whom they chose to employ. ${ }^{21}$ Frank Honigsbaum, in his history of the development of the British medical services, remarks that no other British medical organization "did nearly so much for those who were persecuted by the Nazis" as the SMA. ${ }^{22}$ Indeed the organization's growth in the 1940s was in part due to the recruitment of refugees, a reflection of the former's commitment to the refugee issue and the political predisposition of at least some of the latter.

However, it was mainly the voluntary sector that dealt with nurses during the period in question. There were, in the 1930s, a large and increasing number of organizations concerned with refugees. One of the most prominent was the German Jewish Aid Committee, which had its own Nursing Committee and specifically identified nursing and domestic service as the main areas in which young refugee girls would be trained. ${ }^{23}$ Proliferation and overlap led to the setting up in early 1938 of the Central Co-ordinating Committee for Refugees, popularly known as "Bloomsbury House" after the London location to which it was shortly to move. Of especial note for our purposes was the formation, in late 1938, of the Nursing and Midwifery Department, one of two specialist sub-committees set up by Bloomsbury House at the request of the Home Office (the other was for domestic servants). In itself this suggests that in official circles the question of refugee nurses was being taken seriously, something further witnessed by the official letter sent by the Home Office in September 1938 (shortly after the Evian conference) to the Intergovernmental Committee on Refugees. This remarked that there were in a very limited number of areas work opportunities for refugees, and that these included nursing. ${ }^{24}$ The important officials of the Department, whose central function was to find employment

${ }^{20}$ DSM (2) 5, General Correspondence 1930-1940, correspondence between Ewald Fabian and Charles Brook, Aug. and Sept. 1937.

${ }^{21}$ On the significance of "networks", see Weindling, op. cit., note 3 above.

${ }^{22}$ Frank Honigsbaum, The division in British medicine, London, Kogan Page, 1979, p. 260.

\footnotetext{
${ }^{23}$ German Jewish Aid Committee, While you are in England: helpful information and guidance for every refugee, n.p., n.d., pp. 2, 22. I am grateful to Liselotte Adler-Kastner, daughter of refugees, for showing me this publication.

${ }^{24}$ Lafitte, op. cit., note 13 above, pp. 48-9; Sherman, op. cit., note 2 above, pp. 99, 131.
} 


\section{Refugee Nurses in Britain, 1938-1942}

for Germans, Austrians, and Czechs, were its Chairman, and Matron of St Thomas's Hospital in London, Miss G V Hillyers; its Vice-Chairman, President of the Midwives' Institute and peace movement activist, Miss E M Pye; and its dynamic young Secretary, the daughter of an exiled Austrian doctor, Miss A M Frey. The Department from its formation worked closely with Home Office officials. Indeed the latter greatly relied on it, and it is notable from the records that Miss Frey was in regular contact with the Home Office civil servant E N Cooper whom London identifies as sympathetic to the refugee cause. ${ }^{25}$

The Department was wound up in 1941 to be replaced by a welfare committee for nurses and midwives. As one of its founding organizations, the Central Council for Jewish Refugees, put it, by this point it was "no longer necessary". ${ }^{26}$ A further aspect of this was the apparently unsuccessful attempt by the Ministry of Labour to employ Miss Frey in its International Labour Branch "to centralise the recruitment and placing of nurses" and to widen her brief beyond those nationalities with which the Nursing and Midwifery Department dealt. ${ }^{27}$ The shift from employment to welfare and the plans for Miss Frey further emphasizes that the situation for refugees, and in particular their work situation, had by now considerably eased.

In terms of numbers, we have seen that before 1938 restrictions were placed on the employment of refugee nurses, although these could be partially circumvented; and that thereafter a more liberal approach was adopted. In 1939, a Home Office minister told the Commons that in the previous year 224 permits had been issued to hospitals to employ foreign nurses and that, additionally, permits had been granted to 89 foreign nurses already resident in the United Kingdom who wished to take up hospital posts. In conjunction with the Nursing and Midwifery Department, and outside "normal procedures", a further 63 visas were issued to German women to work in British hospitals. ${ }^{28}$ This was therefore more than in the preceding three years taken together. However, official statistics did not necessarily tell the whole story, even allowing for a rather more "liberal" admissions policy. As the Nursing Times noted in mid-1939, while the refugee situation had taken on particular significance after 1938 there remained obstacles in the path of those who wished to enter the country either already qualified as nurses or seeking to train as nurses or midwives. So, for example, of the 1,567 preliminary applicants for nursing training, 900 had been found suitable, 362 had applied for Home Office permits, and 275 had had permits granted. Of these, however, only 148 had actually arrived in England. There was evidently a combination of external and domestic factors involved here, and to the latter was added the continuing official ruling that the "allocation of refugee nurses is limited to the proportion of three per cent. of the nursing staff". The question of trained nurses seeking employment, the article concluded:

${ }^{25}$ London, op. cit., note 2 above, p. 14 .

${ }^{26}$ LMA Acc/2793/01/13/01, Central Council for Jewish Refugees, Report for 1941, London, 1942, p. 4.

${ }^{27}$ PRO LAB 8/93, undated (but late 1940/early 1941) memorandum from International Labour
Branch. It is not clear what became of this proposal from the files consulted, but, as is noted below, a Miss Powell was responsible for the Branch's nursing section.

${ }^{28}$ Lancet, 1939, i: 544 . 


\section{John Stewart}

raises many difficulties and up to the present time special hospitals or post-graduate work seem to offer the only solution, as the Home Office will not permit their employment in nursing homes. The public demand for skilled nursing for the chronic sick has not yet been met and one wonders if there might not be new opportunities found for trained nurses in this important field. ${ }^{29}$

Clearly, domestic and external constraints continued to operate against those seeking employment as nurses in Britain. ${ }^{30}$ The specific reference to nursing for the chronic sick is also noteworthy. Like mental health nursing-as noted below, a longstanding problem area in nursing recruitment - this particular field may have had especial difficulties in gaining new staff and thus have been identified as a gap which could be filled by refugees.

In the early months of the war the demand for nurses increased and refugees were seen as one way of dealing with this issue. In March 1940, the Medical Officer of Health for the LCC wrote to the Ministry of Health asking if it were possible "in urgent circumstances" to relax already agreed guidelines "particularly with regard to 'friendly aliens'". A few weeks later at a meeting between the Ministry of Health, the Home Office and the Aliens War Service Department it was noted that the latter had received "numerous applications from hospitals to employ alien nurses". 31 Ironically, as we shall see, all this took place immediately prior to the dismissal from employment of certain categories of refugee nurse. In mid-1940 the Nursing and Midwifery Department told the Home Office that 914 trained nurses, midwives, and probationer nurses were in employment, of which 130 were Czechoslovakian and the remainder German and Austrian. This confirms the contemporary observations of François Lafitte who suggested that some thousand nurses had been placed in British hospitals by the Department. We can refine this data further: in September 1939 the Committee of Austrians in England notified the Home Office that 108 female and 6 male nurses were in the country thus suggesting a total of around 650 Germans. This compares with the 1,200 Austrian and German doctors in Britain by 1939, of whom some 200 were permitted to practice. ${ }^{32}$ We can add to the total Bloomsbury House group those who came from countries other than Germany, Austria, and Czechoslovakia. In early 1941, for example, it was noted that there were 111 male and female Polish nurses in Britain (out of a total of 2,486 refugees from that country, including 44 doctors and 15 dentists) although it is not entirely clear whether all were currently in employment. ${ }^{33}$ Refugees might even come from British hospitals abroad, or areas such as the Channel Islands. The War Emergency

\footnotetext{
29 ، "They seek a country": the problem of the refugee nurse', Nursing Times, 2 April 1939.

${ }^{30}$ Although it should be noted that British consular officials sympathetic to refugees issued visas as a means of protecting those individuals, and that some 50,000 visas were in fact not taken up: Sherman, op. cit., note 2 above, p. 7.

${ }^{31}$ PRO MH 58/336, letter from Medical Officer of Health, LCC, 19 Mar. 1940; and note of a meeting between the Ministry of Health, the Home Office and the Aliens War Service Department, 5 April 1940.
}

\footnotetext{
${ }^{32}$ PRO MH 58/336, letter from A M Frey, Secretary, Nursing and Midwifery Department, Bloomsbury House, to E N Cooper, Home Office, 10 Aug. 1940; Lafitte, op. cit., note 13 above, p. 49; Lancet, 1939, ii: 626; Weindling, op. cit., note 3 above, p. 253.

${ }^{33}$ PRO MH 76/515, report on Polish War Refugees in Seventh Meeting of the Central Committee for War Refugees from Holland, Belgium and France, 25 Feb. 1941.
} 


\section{Refugee Nurses in Britain, 1938-1942}

Committee of the RCN noted in July 1940 that "eleven refugee nurses from the Hertford British Hospital, Paris, and four from St. Heliers Hospital, Jersey, had been helped by the College". It is unclear if these women were British nationals, but the posts found for them suggest that at least in some cases they were not. ${ }^{34}$

Overall, although it is difficult to be precise, it would appear that we are dealing in the early part of the war with between 1,300 and 1,500 individuals, and that the total was rising significantly by the time of the general easing of the refugee situation. In October 1941, for instance, the Nursing Mirror noted that since July the Ministry of Labour had interviewed over 400 aliens seeking to become nurses. This was in marked contrast to the number of alien women employed as domestic servants, whose pre-war numbers amounted to around a third of all German, Austrian and Czechoslovakian refugees. By 1941, this field of employment was of negligible importance for refugees. ${ }^{35}$ It is highly likely that the ongoing moves into nursing and out of domestic service were closely related phenomena and that refugee women took the opportunity to enter a profession which was not only of higher status but also led to recognized qualifications. In so doing, female refugees were acting in accordance with the trend among women in general to reject domestic service as an acceptable occupation. I now examine further the issue of refugees as nurses by looking at, first, the mechanisms whereby they might be employed in the period up to the outbreak of war; the official constraints which determined their employment status in the early years of the war; and their actual experiences.

\section{Pre-War Employment}

Before late 1938 the placing of refugee nurses had been, as the Central Council for Jewish refugees noted, carried out on "a small scale" by "private persons" with most of the designated young women being given "hospitality for a short period" on their arrival in Britain so that they might "acquire a knowledge of English" ${ }^{36}$ This might, however, be seen as a rather modest assessment. We have noted the relative liberalism of the Ministry of Labour prior to 1938 and the activities of the SMA on the LCC. Similarly, and again suggesting that restrictions were not quite as tight as officially stated, we find the Nursing Times in mid-1938 noting that a new nurses' home was being built at the London Jewish Hospital, an institution which trained "nurses of many nationalities". "During the present persecution of the Jews in Europe", the article continued, "the hospital is helping refugees, many of whom have been appointed to medical and nursing posts" ${ }^{37}$

None the less, with the advent of the Nursing and Midwifery Department there was a change of pace and organization. In December 1938, the Nursing Times carried a letter from G V Hillyers in her capacity as Department Chair. She explained how

\footnotetext{
${ }^{34}$ Royal College of Nursing Archives (hereafter RCN), RCN 3/14/2, Minutes of the War Emergency Committee, 4 July 1940.

${ }^{35}$ Nursing Mirror and Midwives' Journal, 11 Oct. 1941, p.16; Davidson, op. cit., note 3 above, p. 539 .
} 


\section{John Stewart}

this body had been set up and how in doing so the Association of Hospital Matrons had worked in conjunction with the Co-Ordinating Committee for Refugees. She also laid out the criteria for allowing nurses to enter the country and undertake training. The details of the refugee nursing scheme had been circulated to matrons of training schools "to put before their hospital committees for sympathetic consideration". Miss Hillyers certainly stressed the humanitarian side of the matter, appealing to "all leaders of the nursing profession to assist in extending a helping hand to those who are in great distress at the present time". But she also pointed out that the ultimate aim of training was to fit refugees to "take posts abroad"; and that the "economic side of the question", by which she undoubtedly meant the impact on the domestic labour market, was being "carefully watched by the Ministry of Health and the Ministry of Labour". Commenting on this letter and the refugee situation in general, the Nursing Times was at pains to deny that the letter circulated to matrons of training schools was in any way furtive or secretive and claimed that the scheme had been much discussed in nursing circles. Again showing a mixture of humanitarianism and labour market concerns, it was noted that, given the shortage of nurses, the scheme was a "practical one whereby we can help others and at the same time help ourselves". The latter was to be done not least by "regulating the number of foreign nurses allowed to work in the country and so preventing the hospitals being flooded with refugees". ${ }^{38}$ Care thus had to be taken that British nurses, and indeed the British public, did not feel threatened by the scheme.

It is significant, nevertheless, that the Nursing Times thought the issue important enough to revisit it in a leading article early in 1939. Here the claim that trainee refugee nurses would crowd out potential British nurses was explicitly rejected. The recently-published Interim Report of the Inter-Departmental Committee on Nursing Services was cited and the conclusion drawn that it would almost certainly "be quite impossible to over-recruit the nursing profession for the next five years". Just as no British women should be forced into nursing, so potential refugee trainees should be admitted to training schools "because they wish to nurse, and not merely because nursing is one of the few professions in which the supply does not meet the demand" (my emphasis). Vocation was thus more important than nationality, and labour market competition not an issue. As for already trained foreign nurses, the suggestion that they be found employment in domestic service-like nursing, at that point experiencing labour shortage-was "to waste specialised skill of which this country has need and to allow the skill which their own race will need in the future to deteriorate". The British nursing profession must therefore show that it placed the "service of humanity above merely personal and selfish considerations" and be willing to "take trouble to help those whose need is so great". The piece concluded with the confident assertion that it would not "fail to rise to this difficult occasion". ${ }^{39}$

This clarion call notwithstanding, the actual employers of nurses responded to the Department's scheme in ways ranging from positive support to outright rejection. In a piece entitled 'Solving two problems' the Nursing Mirror noted in early 1939

\footnotetext{
${ }^{38}$ Nursing Times, 10 Dec. 1938 , pp. 1310 , 1301, emphasis in original.
}

39 'The refugee problem', Nursing Times, 18 Feb. 1939, pp. 191-2. 
that some hospitals were addressing the issues of both refugee nurses and the nursing shortage "by associating themselves with the refugee scheme". As the Mirror put it, nursing was "perhaps the one field where an influx of refugees will cause no unemployment problems". Among the participating institutions was the Royal Lancaster Infirmary where refugees were to be employed as soon as accommodation was available. Indeed the secretary-superintendent was quoted as saying: "These nurses are a godsend to British hospitals". ${ }^{40}$ Another positive development occurred at London's General Lying-in Hospital, which was proposing, again in early 1939, to set up a "scheme to train Austrian refugees as midwives". ${ }^{41}$ A similar course was followed at the Royal Infirmary of Edinburgh, whose managers agreed to accept two Austrian women as trainee midwives annually for four years despite the fact that such trainees would not, as had initially been thought, attract Scottish Department of Health grants. ${ }^{42}$ As will become apparent, trainee midwives were both in short supply and, at particular points, offered as a possible solution to the problem of female refugee doctors.

In London, the LCC's Hospital and Medical Services Committee, chaired by the SMA leader, Somerville Hastings, discussed the scheme in early December 1938. It noted that under Standing Orders no non-Briton could be employed except under particular circumstances, which included the "pursuance of a special resolution of the committee concerned". The Committee further noted that the issue of refugee nurses had been raised recently not least because of what it rather coyly described as "developments in the European situation". It thus agreed to support the Nursing and Midwifery Department's scheme to the extent of accepting two candidates for probationer nurse at each of the 37 training schools under the Committee's management. These consisted of 27 general hospitals (giving 4 years training), 9 fever hospitals (giving 2.25 years training), and Queen Mary's Hospital for Children (giving 3.25 years training). Various conditions were placed on potential candidates, including the ability to speak English. Furthermore, the Committee declined to "recommend the acceptance of fully-trained refugee nurses on the trained nursing staff or of refugees as assistant nurses", the former of which, as we shall see, would have in any event been illegal under the 1919 Nurses Registration Act. ${ }^{43}$ These provisos notwithstanding, this was a relatively generous response, and testament both to the size of the LCC's health care provision and to the pro-refugee attitude of the SMA majority on its Hospital Committee. Consequently, on the eve of the dismissal of enemy aliens in summer 1940, a total of 64 probationer nurses were employed by the LCC, of which 37 were German, 16 were Austrian, 6 were Czechoslovakian, 3 were Polish, and 2 were stateless. ${ }^{44}$

\footnotetext{
${ }^{40}$ Nursing Mirror and Midwives' Journal, 18 Mar. 1939, p. 839.

${ }^{41}$ Nursing Mirror and Midwives' Journal, 11 Mar. 1939, p. 807.

${ }^{42}$ University of Edinburgh, Special Collections, Lothian Health Services Archives (hereafter LHSA), LHB 1/1/70, Royal Infirmary of Edinburgh, Minutes of the meeting of the Managers, 20 March 1939 and 3 April 1939.
}

\footnotetext{
${ }^{43}$ LMA LCC/MIN/2215, Minutes of a meeting of the Hospital and Medical Services Committee, 8 Dec. 1938.

${ }^{44}$ LMA LCC/PH/WAR/3/83, memorandum of 13 April 1940 concerning the employment of aliens by the Public Health Department.
} 
Greenock Corporation's Public Health Committee agreed, shortly before the outbreak of war, to accept into the Rankin Hospital six refugees from Germany, Austria, or Czechoslovakia as pupil-midwives. This decision, however, had not been easily reached. The Chairman of the Public Health Committee had acknowledged the problem of recruiting midwives, but "thought that there were enough suitable women in this country without calling on foreign refugees". The Medical Officer of Health, however, had argued the urgent need for pupil-midwives and, indeed, that the institution might have to close were these refugees not recruited. A compromise of sorts was reached in that the Corporation agreed to allow the recruitment of refugees but, none the less, "decided to ask for a guarantee that they would not remain in the district and compete with nurses in Greenock after completing their training". ${ }^{45}$ We can again see here a tension between labour market pressures and anti-foreigner sentiment. In Edinburgh, the Corporation's Hospitals Sub-Committee agreed to support Miss Frey's scheme, which it in turn recommended to its parent body, the Public Health Committee. Although the latter went along with this decision, it did so only after a debate and on a split vote. ${ }^{46}$ And, of course, since the scheme had no measure of compulsion behind it, its arguments could be rejected outright. Gateshead Public Assistance Committee in January 1939 passed a resolution in response to the Nursing Department's circular "refusing to accept two refugee nurses as probationers at Gateshead Institution for the next four years". ${ }^{47}$

\section{Employment, Unemployment, and Regulations}

With the coming of war, the situation of refugee nurses became more complex still. We have seen that restrictions on employment were in place before September 1939. After that date, employment of nursing staff became more centralized than had previously been the case and, furthermore, where refugee nurses, and particularly those from enemy countries, would be allowed to work became a sensitive issue. Of especial concern was whether non-British nurses should be allowed to work in the restricted areas; and whether they should be allowed contact with injured members of the armed forces. The latter had been anticipated before the outbreak of war so that, for example, the CECNP noted in late August 1939 that the "the allocation of nurses, assistant nurses, or nursing auxiliaries of foreign nationality needs special consideration". It was at this stage only advised - it was later to be compulsory - that refugee nurses should not be allocated or otherwise placed in any situations where they might come into contact with military casualties. ${ }^{48}$ As noted earlier, however, the situation became particularly difficult for all refugees in late spring and summer 1940.

\footnotetext{
${ }^{45}$ Lancet, 1939, ii: $573-4$.

${ }^{46}$ LHSA, LHB 13/9/12, Edinburgh Corporation, Minutes of the meeting of the Hospitals Sub-Committee, 14 Feb. 1939, and Minutes of the meeting of the Public Health Committee, 21 Feb. 1939.
} 
In April of that year, the Nursing Committee of the Elizabeth Garrett Anderson Hospital in London noted a letter from the Aliens War Service Department concerning two of its nurses, the Misses Munz and Illing, and an Austrian radiographer, Miss Heyman. The Committee was required to undertake that these employees would have no contact with services personnel and, rather grudgingly, this was agreed. The following month it received a further communication from the same body "informing the hospital that no permits would be given for alien members of the staff to continue working on the premises". Again rather grudgingly, the Committee agreed to implement these instructions by the end of the month. ${ }^{49}$ The German Hospital at Dalston, London, noted in its official reports that at the outbreak of war all of its German doctors had left, but around half of its German nursing sisters (out of a total of 56) had remained in post. The following May, however, "our German sisters $\ldots$ left and the vacancies were filled by ... British nurses"..$^{50}$ This was a rather circumspect way of acknowledging official requirements.

At the beginning of June, some local authorities, notably the LCC, dismissed their enemy alien staff. The LCC's Medical Officer of Health, W Allen Daley, issued a "Secret, Confidential and Immediate" order requiring that the "services of all German, Austrian or stateless aliens are to be terminated forthwith". This was followed ten days later by Ministry of Health circular 2045 which required all hospitals and similar institutions under the control of the Emergency Medical Scheme immediately to dismiss from their staffs all Austrians, Germans, and Czechoslovakians (and subsequently Italians) irrespective of whether these hospitals were in areas planned to take military or civilian casualties. The Czechoslovakians in particular felt a justified sense of grievance about their dismissal. The Czechoslovak Welfare Association wrote to the Home Office in mid-June with an "urgent request from Czechoslovak doctors and nurses in Great Britain, who are denied their one ambition, which is to help the Allied cause". The further Ministry of Health circular 2080 of 3 July, allowed for the re-employment of Czechoslovakian nurses in hospitals receiving military casualties, and for Germans, Austrians, and Italians to be employed in hospitals not receiving such patients. This prompted the Nursing and Midwifery Department to send a resolution to the Home Office seeking the reinstatement of all refugee nurses, including those still banned under circular 2080. ${ }^{51}$ In London the specific case of Czechoslovakian nurses does not appear to have been acted upon until September, when the Hospital and Medical Services Committee agreed to the

\footnotetext{
${ }^{49}$ LMA H13/EGA/67, Minutes of a meeting of the Nursing Committee, 25 April and 23 May 1940. The nationalities of Miss Munz and Miss Illing are not clear, but they were obviously classed as "enemy aliens".

${ }^{50}$ German Hospital, 95th annual report for the year ending 31st December, 1939, London, 1940, p. 7, and 96th annual report for the year ending 31st December 1940, London, 1941, p. 6.

${ }^{51}$ PRO MH 58/333, letter from W Allen

Daley, 1 June 1940; also circulars 2026 and 2045. For the formal, public announcement of the ban in London, see Minutes of the London County
}

Council, 25 June 1940; PRO MH 58/336, letter

from A M Frey, Secretary, Nursing and Midwifery Department, Bloomsbury House, to E N Cooper, Home Office, 10 Aug. 1940; PRO MH 58/335, letter from the Czechoslovak Welfare Association to the Home Office Aliens Department, 18 June 1940; PRO HO 213/521, letter and resolution from the Nursing and Midwifery Department to the Home Office, 30 Aug. 1940 - this file also contains official correspondence between various government departments on the Czechoslovak situation. 
re-employment of Czechoslovakian probationers. London's stalling was the subject of some official concern. A week before the LCC decided on reinstatement, a Ministry of Labour official remarked that it would "probably go a long way in influencing other hospital authorities" if the council took back its Czechoslovakian nurses, and that in total this would lead to "about 80 " such individuals re-entering employment. It is possible that pressure was exerted on the council to this end.

The Nursing and Midwifery Department was therefore engaged in finding alternative work and training for those dismissed. Some had been sent to hospitals and training schools not receiving military casualties, some had gone into private or domestic nursing, and a few had been found what was described as "miscellaneous employments". ${ }^{52}$ However, it was not only the Department which took an interest in these unemployed nurses. Official correspondence between the Home Office and the Ministry of Health in August 1940 noted that as a result of the recent restrictions "between 700 and 1,000 nurses of enemy nationality were now without employment". It had been suggested by some civil servants that it would be better if such individuals were re-employed by the hospitals since then "they would be under adequate supervision rather than ... left at large where there was much more likelihood that they could engage in activities to the detriment of national security". This suggestion appears to have been vetoed by the Aliens Department and MI5, although both agreed it was worthy of consideration. Interestingly, the Home Office and the secret service seem to have thought that when it came to surveillance doctors and nurses should be treated differently and it is highly likely they came to this conclusion on gender grounds. ${ }^{53}$

As even such a cursory account of official regulations suggests, here was a complex situation. It is apparent from the records that confusion existed between government departments as to how the rules pertaining to refugee nurses and other medical workers, especially those from Germany, Austria, and later Italy, should be applied, although a persistent theme was that there should be no contact between enemy aliens and injured service personnel. ${ }^{54}$ Understandably, local authorities and individual hospitals too were often baffled. The LCC's Hospital and Medical Services Committee agonized at considerable length in 1940 and 1941 over rules relating to employment and training. ${ }^{55}$ To give an individual example, Miss Heyman, the Elizabeth Garrett Anderson radiographer, was, in a period of six months, dismissed, erroneously re-employed, suspended pending an appeal to the Aliens Department who wanted her dismissed again, and eventually given a "special permit" to work. ${ }^{56}$ The rules concerning Czechoslovakian nurses in summer 1940 were especially complex, with Miss Frey pointing out their internal contradictions to the Home Office in the autumn of that year and remarking that "Matrons themselves were extremely

\footnotetext{
${ }^{52}$ LMA LCC/MIN/2217, Minutes of the Hospital and Medical Services Committee, 10 Sept. 1940; PRO LAB 8/93, memorandum of 2 Sept. 1940.

${ }^{53}$ PRO MH 58/336, letter from Home Office (Aliens Department) to Ministry of Health, 16 Aug. 1940.
}

\footnotetext{
${ }^{54} \mathrm{See}$, for example, the correspondence in PRO LAB 8/93.

${ }^{55}$ LMA LCC/MIN/2217 and 2218 passim.

${ }^{56}$ LMA H13/EGA/67, Minutes of a meeting of the Nursing Committee, 13 June, 11 July, 14 Nov., and 12 Dec. 1940.
} 
puzzled by this conflict of regulations". This followed on from an earlier letter which had pointed out, quite reasonably, that no matron "could staff her hospital in such a way as to render it liable in a moment of emergency and consequent increase of work to a sudden dismissal of Nurses". ${ }^{57}$

Eventually, however, there was an easing of restraints although official concerns remained over enemy aliens, especially regarding what might happen in the event of a national emergency. In November 1940, for example, German, Austrian, and Italian nurses were allowed to be employed in Emergency Medical Service hospitals in areas officially classified as not liable to attack or invasion. Employment permits from the Aliens War Service Department had to be obtained, but "they will usually be readily granted". Such nurses should, none the less, where at all possible, be employed in wards where British staff were also working, and the total number of aliens (that is, nurses, doctors, and students) should not exceed 10 per cent of the workforce ( 20 per cent in hospitals of less than 100 beds). What is notable here is that while quotas remained, and were clearly seen as in the interests of national security, the exigencies of war had enlarged them from what was anticipated before the conflict broke out. Finally, it was pointed out that, should a "serious military situation" arise, the authorities might require hospitals to dismiss immediately all enemy aliens. ${ }^{58}$ It was also the case that reservations about the employment of enemy aliens persisted among employers themselves. In April 1942, the Executive Committee of the SMA wrote to the LCC protesting at the latter's decision to limit the number of enemy aliens employed by its Public Health Service to six, below the level allowed by current government regulations. ${ }^{59}$

However, there is no doubt that a change in attitude had taken place, partly because of greater sympathy for refugees in general, partly because of ongoing labour market concerns. In September 1942, for instance, the LCC agreed to a request from 37 Austrian nurses employed in its hospitals that they be allowed to participate, wearing indoor uniform, in the concluding meeting of the Austrians for Britain Campaign. ${ }^{60}$ This was a much more relaxed approach than would have pertained two years previously, almost certainly in part attributable to the growing belief that the Allies would now win the war. On the labour market front, both the Home Office and the Nursing and Midwifery Department were quick to see parliamentary pronouncements in spring 1941 on the shortage of nurses as opportunities to promote the cause of refugee women. ${ }^{61}$ At the Home Office, a civil servant closely associated with the refugee nurses' situation commented to a colleague that if the shortage in hospitals was as great as indicated in the Lords debate then there should be "little

\footnotetext{
${ }^{57}$ PRO HO 213/521 letter from Miss A M Frey, Nursing and Midwifery Department, to E N Cooper, Home Office, 18 Oct. 1940; PRO MH 58/336, letter from Miss A M Frey, Nursing and Midwifery Department, to E N Cooper, Home Office,' 10 Aug. 1940.

${ }^{58}$ Lancet, 1940, ii: 632.

${ }^{59}$ DSM 1/6, EC Minutes, 30 April 1942. 1942.
}

\footnotetext{
${ }^{61}$ See Parliamentary Debates 5th Series (Lords), vol. 119, cols $31-6$ for a debate on the staffing problems of hospitals; and Parliamentary Debates 5th Series (Commons) vol. 370 for, first, a debate on 'Womanpower' in which Florence Horsburgh pointed to the need for more nurses (cols 362-8) and, second, for the subsequent statement by the Minister of Health, Ernest Brown, specifically repeating this point (cols 1168-73).
} 


\section{John Stewart}

difficulty" in placing refugee women in either nursing or non-nursing posts. Shortly afterwards, Bloomsbury House noted that it had sent the International Labour Branch of the Ministry of Labour-now the official body responsible for placing refugees in work - detailed information on how refugee women could gain employment. Nursing was given a prominent place in these suggestions and it was argued that the profession "thus offers a special opportunity for following an urgent present need and at the same time of training for the future". The recent comments of the Health Minister, Florence Horsburgh, on women's role in the war effort were used to substantiate this claim. ${ }^{62}$ Such was the optimism about the potential of nurse training that in late 1942 one member of the Central Committee for Refugees wondered aloud how refugee girls who left school at fourteen could best fill in their time before becoming probationer nurses at the age of eighteen. ${ }^{63}$

However, official optimism about employment needs to be understood in the context of a further restriction placed on refugee nurses. We have noted the unwillingness of the LCC in the late 1930s to accept any refugees into the category of fully-trained nurse and that this was in part justified by reference to the 1919 Nurses' Registration Act. The Act made no provision for those trained outside the British Empire to be accepted as State Registered Nurses, and this was upheld by the General Nursing Council, the body charged with overseeing the content and conduct of nurses' training. This meant that the highest grade at which a fullytrained refugee nurse could be employed without going through the prescribed British training was assistant nurse. The only exception to this appears to have been London where, its pre-war stance notwithstanding, the LCC employed some refugees as deputy sisters.

The situation in respect of refugees was clearly brought out in a Commons exchange in spring 1942. An MP asked the Minister of Health whether there was any move to change the requirements of nursing registration to accommodate the qualifications held by some refugee nurses. Florence Horsburgh replied that there was no intention of amending the 1919 Act. What needed to be understood, however, was that refugees could be employed as assistant nurses and did not have to start as either probationers or students. Questioned further by another formidable female politician of the period, Eleanor Rathbone, who was also Secretary of the Parliamentary Committee on Refugees and a member of the Central Committee for Refugees, on whether consideration should be given to German nurses who were opponents of Nazism, Miss Horsburgh responded: "It is not the fact of being aliens but the training they have had, and whether they should be classed as assistant nurses or student nurses or fully state-registered nurses" ${ }^{64}$ On at least one front, however, the status issue was to become more relaxed. By 1943 the Council of British Societies for Relief Abroad was making plans for medical care as more and more

\footnotetext{
${ }^{62}$ PRO HO 213/523, Home Office correspondence of 25 April and 23 May 1941; and PRO HO 213/523, copy of circular 100 , Central Office for Refugees, 6 June 1941.
}

\footnotetext{
${ }^{63}$ LMA Acc/2793/03/01/01, Minutes of the fourteenth meeting of the Central Council for Refugees, 10 Dec. 1942.

${ }^{64}$ Lancet, 1942, i: 339.
} 
parts of Europe were liberated, and it is clear that it accepted both British state registration and its "foreign equivalent" in the nurses it was to employ. ${ }^{65}$

There was another dimension to this issue of qualifications and status. As previously noted, pre-war British doctors and their organizations were extremely hostile to the admission of refugee medical practitioners on the grounds of labour market fears and, in some cases, anti-Semitism. One potential solution was a conscious strategy to have female refugee doctors employed as nurses. This was an approach employed by the SMA in responding to its contacts abroad and in utilizing its position on the LCC. So, for example, late in the troubled year of 1938 a leading Association official wrote to the General Secretary of the Labour Party that "a good deal of the suffering of exiled doctors would be ameliorated" if they were to be employed as nurses. It was further pointed out that many local authorities, and thereby hospitals, were Labour controlled. The letter concluded: "we beg you to use your influence with them to further this scheme". A few weeks earlier a similar approach had been made to the London Labour Party by the SMA's London branch arguing that if the LCC were to "employ as many possible refugee doctors as nurses in its hospitals, the great suffering of jewish [sic] and progressive doctors in fascist countries would be to that extent ameliorated" and asking that the Party without delay "get in touch with the London County Council to persuade that body to adopt this measure". Interestingly, some potential refugee doctors appear themselves to have adopted the nursing strategy as a way of entering Britain. In early 1939, the SMA received a letter from the International Socialist Medical Association seeking help on behalf of Miss Dr Jacoby, a German doctor currently in Prague. Dr Jacoby was seeking a nursing post in England and had written to the LCC's Matron-in-Chief citing Charles Brook's name. Poignantly, the letter ended with the comment: "There are letters from everywhere and we can only help a little". ${ }^{66}$

The idea was also taken up by the Nursing and Midwifery Department. By summer 1939 a scheme had been devised whereby women refugee doctors were to be sent to midwifery training schools for two years before a further two years' work in rural districts. As the Lancet rather brutally put it, the "intention is that [these refugee midwives] should eventually emigrate". An appeal was put out for doctors to donate old midwifery textbooks to help these refugees with their studies ${ }^{67}$ Oral testimony gives further evidence of the use of doctors as midwives. A young nurse in Birmingham in the 1970s later recalled caring for a woman on a ward for the elderly mentally ill. The patient was known to have been a midwife but staff dismissed her claims to have also been a medical practitioner. However, after investigation by the woman's family - who themselves were unaware of this claim-it transpired that she had

\footnotetext{
${ }^{65}$ University of Southampton, Special Collections, Schonfeld Papers (hereafter Schonfeld Papers), MS 183, 234, folder 1, Report from the Medical and Public Health Sub-

Committee of the Council of British Societies for Relief Abroad, 1943.

${ }^{66}$ DSM (2) 5, 'General Correspondence 1930-1940', correspondence Dec. 1938 between
}

D F Buckle and James Middleton; DSM

(3)/14/32, letter from D M Pryce, Secretary of

SMA London Branch, to London Labour Party,

19 Nov. 1938; DSM (2) 5, 'International', Ewald

Fabian to D F Buckle, 3 Feb. 1939.

${ }^{67}$ Lancet, 1939, ii: 295. 


\section{John Stewart}

indeed been a doctor in Poland. She had fled her native country at the German occupation and, on reaching England, had retrained in midwifery. ${ }^{68}$

It was clearly assumed by both refugee women doctors themselves and their British hosts that nursing offered an appropriate and valuable way of gaining employment in Britain, notwithstanding that this was work of a different type and status than previously. Of course, some male refugee doctors also found themselves, because of the restrictions on employment, in ancillary occupations. But their female counterparts were specifically targeted for nursing posts, undoubtedly on gender grounds, and were also themselves prepared to countenance such employment as a pragmatic response to prevailing circumstances. Such flexibility was particularly apparent among those female doctors who had been radicalized by the experience of Weimar Germany ${ }^{69}$ This gender dimension of refugee experience is further illuminated by the historian Marion Berghahn in her discussion of German-Jewish women refugees in Britain. She argues that:

women proved to be more adaptable than men ... On the whole, women were more flexible and ready to grasp whatever opportunity offered itself to boost the meager family income ... Because of the restrictive economic and social measures that the Nazi regime forced upon the Jewish community, women in particular had started to make adjustments already in Germany to the changed climate and had lowered their expectations of education, status, and employment long before emigration. ${ }^{70}$

The more instrumental approach on the part of these particular female refugees suggests both adaptation to the host environment and an awareness that the nursing and medical practitioner labour markets were very different.

It was almost certainly also the case that for many female refugees without prior training the opportunity to enter the nursing profession in itself offered the possibility of an acceptable career, not least because nursing in Britain enjoyed a higher status than in some other European countries. German refugees, for instance, would almost certainly have been aware of the total subordination of nursing in their native country to the Nazi project. ${ }^{71}$ This is not to imply, however, that refugees already trained as nurses passively accepted the effective devaluation of their qualifications by the British authorities. Evidence here is sketchy but it is notable that, for example, a series of talks was given at the Czechoslovak Institute in 1943 which included four

\footnotetext{
${ }^{68}$ The young nurse was David Wright, now Lecturer in the Department of Mental Health and Learning Disability, University of Sheffield. I am grateful to him for sharing this recollection with me, in the first instance at the 'Cinderella Services' Conference at South Bank University.

${ }^{69}$ On these, and the problems faced by refugee women doctors, see Anita Grossman, 'New women in exile: German women doctors and the emigration', in Quack (ed.), op. cit., note 3 above, pp. 215-38.

${ }^{70}$ Marion Berghahn, 'Women émigrés in England', in Quack (ed.), op. cit., note 3 above, pp. $69-80$, on p. 76 . This point is picked up in
}

the same volume, p. 88 , by Susanne Miller, a leftwing Austrian political activist exiled in Britain.

${ }^{71}$ I am grateful to Professor Paul Weindling for this point. On nursing under Nazism, see Hilde Steppe, 'Nursing under totalitarian regimes: the case of National Socialism', in Rafferty, Robinson and Elkan (ed.), op. cit., note 5 above, pp. 10-27. For a North American perception on the higher standing of British nursing compared with that in Europe, see Anne Marie Rafferty, 'Internationalising nursing education during the interwar period', in Paul Weindling (ed.), International health organisations and movements, 1918-1939, Cambridge University Press, 1995, pp. 266-82. 
contributions on the pre-1938 health services. In turn, one of these was specifically devoted to the training of doctors, nurses, and social workers. ${ }^{72}$ Such pride in their training and vocation is an appropriate point at which to turn to how refugee nurses experienced the employment in which they found themselves.

\section{Experiences}

In spring 1942, Miss A Powell, the official responsible for the nursing section of the Ministry of Labour's International Branch, gave a public address on 'Allocating the alien'. She told her audience of the "overwhelming" number of aliens who "thronged" her department, and how interviews were often conducted not only in English but also in French or German. Miss Powell further noted that most "girls" wanted to train in the London voluntary hospitals, but that this was complicated by the capital's restricted area status. Hospitals for specific national groups offered opportunities for some nurses - she cited the Norwegians and Poles as among these-but others wished to take the opportunity to avail themselves of English training. These comments bear out the points made earlier about the demand for nursing labour and the appropriateness of using refugees to this end; and the attractiveness of the profession to refugee women. Giving an insight into contemporary attitudes, Miss Powell remarked that initially many matrons did not wish to employ Germans or Austrians but that "this prejudice gradually died" as these groups were found to be good workers. Reports on refugee nurses' work were on the whole favourable, and out of "hundreds" placed only five had been dismissed. Overall, therefore, every effort was being made to "secure for the alien in nursing sympathetic treatment, for most of the applicants had had tragic experiences". On the other hand, Miss Powell further remarked, "even in those hospitals which did take them there was apt to be hostility". ${ }^{73}$ We can discern here a broadly sympathetic official attitude combined with continuing problems of popular prejudice; and, perhaps, an eagerness on the part of the refugees to show themselves as willing and committed nurses.

These points had been made earlier by the tireless Miss Frey. Writing to the Home Office in the wake of the dismissals of 1940, she pointed out that she had contacted the matrons of the training schools formerly attended by the refugee nurses seeking references and reports on their behalf. These were, she noted, "excellent", with many having "passed Hospital and General Nursing Council examinations successfully ... won prizes, and ... altogether been very satisfactory candidates". On the other hand, she acknowledged that re-employment was not simply a matter for matrons alone. The decision ultimately lay with the hospital or local authorities "and these larger bodies include anti-alien voices which naturally influence the decision". Indeed it is clear that Miss Frey had been asked by the Home Office to investigate the attitudes

\footnotetext{
${ }^{72}$ Schonfeld Papers, MS 183, 234, folder 1, circular of the Committee of British Societies for Relief Abroad, 20 Aug. 1943, refugee women doctors, see Grossman, op. cit., note 69 above, pp. 215-38.
} 


\section{John Stewart}

of both patients and staff towards refugee nurses. While there had undoubtedly been problems, there had not been a "serious menace" and when difficulties had arisen they had generally been overcome "by tactful intervention on the part of the Matron or the Committee". ${ }^{74}$ The positive issue of achievement was also picked up elsewhere. The Nursing Mirror, in the article noted above on the volume of refugees seeking nursing employment in 1941, remarked further that a number of these were male. Were they as "keen and intelligent as most of their female counterparts", it continued, "they will be a useful addition to the lessening number of male nurse trainees". It was "notable", the piece concluded, that "in the prize lists printed in this issue, the names of several alien nurses are to be found". ${ }^{75}$

It is further evident that, even after dismissal, some refugees were anxious to return to nurse training and did so successfully. At Birmingham General Hospital two German Jewish refugees, one of whom had been previously employed in the Jewish Maternity Hospital in Berlin, were employed in 1938. Both were duly dismissed in summer 1940, but eventually gained state registration, one apparently in Birmingham itself and the other at the London Homeopathic Hospital. The latter was described by her former employers in Birmingham as a "very good nurse in her months here", while the former was seen as a "promising, nice girl, willing worker-kind". Although other refugees were seen in a less positive light, the very fact of good and less good comments suggests that these young women were being judged on professional rather than racial or national grounds. ${ }^{76}$ The attitude of the GNC is worth noting here. It was not prepared to change its rules for registration. But it is also clear from official records and from the comments of Miss Frey that it viewed sympathetically those refugees whose training had been interrupted by dismissal. ${ }^{77}$ Ultimately, some refugee nurses, for example, Annie Altschul and the socialist activist Marion Ferguson, were to go on to great heights in the nursing profession. $^{78}$

There is evidence, moreover, that refugee nurses and their institutions had a sense of mutual loyalty and that at least some hospitals continued to look sympathetically upon the refugees' plight even in the fraught summer of 1940. That August, in an article principally concerned with attempting to explain the complex regulations then in force, the voluntary sector journal The Hospital, none the less, urged that hospitals "should do their utmost to avoid any unnecessary hardship to any alien probationers they may have on their staff", ${ }^{79}$ In December 1940, the Matron at Guy's Hospital in London received letters from two former probationers, Miss M Duncombe and

\footnotetext{
${ }^{74}$ PRO MH 58/336, letter from A M Frey, Nursing and Midwifery Department, to E N Cooper, Home Office, 10 Aug. 1940.

${ }^{75}$ Nursing Mirror and Midwives' Journal, 11 Oct. 1941 , p. 16.

${ }^{76}$ Birmingham City Archives, GHB 133, General Hospital Birmingham, Register of Nurses, Oct. 1937-Jan. 1943. I am grateful to Stuart Wildman, University of Birmingham, for sending me this information, which derives from his own research in nursing history.
}

\footnotetext{
${ }^{77}$ See the comments in PRO LAB 8/93, memorandum of 2 Sept. 1940; and PRO MH $58 / 336$, letter from A M Frey, Nursing and Midwifery Department, to E N Cooper, Home Office, 10 Aug. 1940.

${ }^{78}$ Weindling, op. cit., note 3 above, p. 254 and note 78 .

${ }^{79}$ The Hospital, Aug. 1940, p.190.
} 
Miss S Goldschmidt. These two, dismissed under the regulations applying earlier in the year, now sought re-instatement in the hospital's Nursing School. Despite the hospital's location near the centre of London at a time of great danger during the Blitz, this was readily agreed to by the Governors, the only proviso being the formal one of approval by the Home Office.$^{80}$ At the Edinburgh Royal Infirmary, Nurses Lowenstein, Reiss and Blumenfeld were, as required, suspended from duty in summer 1940. But the managers agreed to allow Reiss and Blumenfeld, who had no other place to go, to remain in their hospital accommodation "pending some satisfactory arrangement". ${ }^{81}$

We have already noted that the Elizabeth Garrett Anderson Hospital appears to have gone to some pains to retain its Austrian radiographer, and it was also quick to re-employ a dismissed Czechoslovakian nurse, Miss Weiss, in July $1940 .^{82}$ These experiences might, however, have contributed to its Nursing Committee's decision not to take on any more alien probationers despite requests from, among others, the Nursing and Midwifery Department. None the less, in mid-1941 the Committee discussed a letter from the Headmistress of the County High School for Girls at Loughton in Essex. This requested that the hospital "accept Miss Ella Schindler a German Jewess for training”. Miss Schindler, whose parents were among the large number of Jewish refugees in Shanghai, was seventeen and a half years old and had been in England since early 1939. The Nursing Committee agreed to accept her as a probationer. ${ }^{83}$ As well as showing a humane attitude towards this particular young woman, this incident again illustrates the easing of tensions by this time. It is also possible that the process of assimilation for at least "friendly" aliens was helped by their being so identified. A photograph from 1941, for instance, shows Czechoslovakian nurses in uniform, one distinctive characteristic of which was a shoulder badge in what was almost certainly the national colours and surmounted by the words "Czechoslovak Nurse" ${ }^{84}$

Again on a nationally-based level we have noted the participation of LCC nurses in the Austrians for Britain campaign, while in early 1940 what was clearly an emotional meeting took place between a group of Czechoslovakian nurses and the exiled President of Czechoslovakia, Dr Eduard Beneš. At this event, which was also attended by some of the matrons of the training schools in which the refugees had recently finished their training, the nurses gave an oath of service to their country. This concluded with the promise to "respect the moral dignity of ourselves and all others, to combat the evil and suffering of humanity, and thus bring renewed honour and prosperity to our beloved country". According to the press report, the nurses

\footnotetext{
${ }^{80}$ LMA H9/GY/A26/1, meeting of the Emergency Committee of the Governors, 10 Dec. 1940.

${ }^{81}$ LHSA LHB 1/1/71, Royal Infirmary of Edinburgh, Minutes of the meeting of the Managers, 10 June 1940.

${ }^{82}$ LMA H13/EGA/67, Minutes of a meeting of the Nursing Committee, 11 July 1940.

${ }^{83}$ LMA H13/EGA/67, Minutes of a meeting of the Nursing Committee, 25 July 1940. The
}

\author{
decision not to take on alien probationers was \\ confirmed at the meeting of 13 Feb. 1941, and \\ Miss Schindler's case was heard at the meeting of \\ 10 July 1941; on Shanghai, see David Kranzler, \\ 'Women in the Shanghai Jewish refugee \\ community', in Quack (ed.), op. cit., note 3 \\ above, pp. 129-38. \\ ${ }^{84}$ Supplement to Nursing Mirror and \\ Midwives' Journal, 5 April 1941.
}




\section{John Stewart}

wished to work either in the Czechoslovakian hospital in England or in France. The piece concluded that every British nurse would wish them "God speed". ${ }^{85}$ Ironically, this meeting took place just prior to the fall of France and the subsequent, albeit temporary, dismissal of Czechoslovakian nurses from posts in British hospitals. Perhaps unsurprisingly, therefore, shortly thereafter, the Czechoslovak Welfare Association proposed to the Ministry of Health the setting up of a Czechoslovakian Nursing Home with attached out-patients clinic, with the strong implication that this be staffed by Czechoslovakian nurses. ${ }^{86}$ And, in line with Miss Powell's remarks noted above, a special Norwegian unit was set up at Craiglockhart Hospital in Edinburgh. The unit's senior nurse was Norwegian and it seems reasonable to assume that most, if not all, of the nursing and medical staff would be of that nationality. ${ }^{87}$

Support in the workplace might also come from external bodies. In summer 1942, the Chief Rabbi's Religious Emergency Council wrote to the Matron of Claybury Hospital, an LCC mental institution, noting that she had granted her Jewish staff leave during previous religious holidays and asking that she might do so again. ${ }^{88}$ While it is unclear whether refugees worked at this particular institution-although given its location, ownership, and the longstanding practice of British asylums employing foreign staff ${ }^{89}$ there is a strong possibility that it did-it seems unlikely that the Chief Rabbi would not have sent similar requests to hospitals where they did. Outside the hospital various opportunities were afforded to refugee nurses either to mix with British colleagues and sympathisers or with their own compatriots. The RCN offered "hospitality at the College once or twice a week, when members of the official staff addressed [refugee nurses] on current affairs". ${ }^{90}$ After the outbreak of war, a London house was put at the disposal of the Nursing and Midwifery Department to be used as a nurses' rest home, and this was further subsidized by the British government. ${ }^{91}$ The SMA provided a forum for social contact between its members and left-wing medical refugees through the efforts of a committee set up specifically for this purpose. ${ }^{92}$ For religiously strict Jewish refugees, a body organized by the Chief Rabbi noted in its report for 1941 that in the course of the year ten welfare and religious centres had been opened, and that in London, with the support of the LCC, two kosher canteens were available for refugees. ${ }^{93}$

\footnotetext{
${ }^{85}$ Nursing Mirror and Midwives' Journal, 9 Mar. 1940, p.1.

${ }^{86}$ PRO MH 58/335, letter from the Czechoslovak Welfare Association to the Ministry of Health, 8 July 1940; on the experience of Czechoslovakian refugees in general, see London, op. cit., note 2 above, especially ch. 6 .

${ }^{87}$ LHSA, LHB 13/9/12, Edinburgh

Corporation, Minutes of the meeting of a Special Sub-Committee of the Public Health Committee, 19 Dec. 1941.

${ }^{88}$ Schonfeld Papers, MS 183, 981/1, letter from the Chief Rabbi's Religious Emergency Council to the Matron, Claybury Hospital, 17 Aug. 1942.
}

\footnotetext{
${ }^{89}$ I am grateful to Kerry Davies, Oxford Brookes University, for this point.

${ }^{90} \mathrm{RCN} 3 / 14 / 2$, Minutes of the War Emergency Committee, 5 Sept. 1940.

${ }_{91}^{1}$ LMA Acc/2793/01/13/01, Central Committee for Jewish Refugees, Report of 1939, London, 1940, p. 14, and Report for 1941, London, 1942, p. 4.

${ }^{92}$ DSM 1/1, Report of the Executive Committee, May 1939-April 1940.

${ }^{93}$ Schonfeld Papers, MS 183, 234, folder 2, Chief Rabbi's Religious Emergency Council, Extract from Report of Activities, period ending 31 st December 1941.
} 


\section{Conclusions}

With qualifications to be returned to, the history of refugee nurses in the late 1930s and early 1940s can be seen as an episode which reflected well on both the host community and the nurses themselves. ${ }^{94}$ Prior to 1938 severe restrictions applied to the entry of refugees to Britain, and the Ministry of Labour was prepared to admit only a relatively small number of nurses. On the other hand, we have also seen that there were loopholes in this system and that civil servants might be more open to making exceptions of groups like nurses than their official stance might otherwise allow. After 1938, the number of refugees increased significantly and we find a voluntary body, the Nursing and Midwifery Department, co-operating with Home Office officials to find refugees suitable nursing employment. This appears to have been a mutually satisfactory way of working, in that a significant number of nurses were employed, although it must be acknowledged that favourable labour market conditions pertained at the time. With the coming of war, the operations of the labour market almost certainly facilitated a shift for refugee women from low status domestic service to higher status nursing. There is, also, evidence that refugee nurses worked hard both before and after 1939 to impress their employers. This was manifested by the mutual loyalty between the two; the achievements of individual nurses in various examinations; and the gradual acceptance of even "enemy aliens" by the medical services. For the most part, the nursing profession had reason to commend itself on its attitude towards refugees, in marked contrast to its medical colleagues.

It would be wrong, however, to suggest that the refugee nurses' experience was unproblematic. In 1933, the College of Nursing sought to keep refugees out of nurse training, a reminder of how sensitive labour market issues were. In other circumstances, therefore, the profession might have been rather less accommodating of refugees than it actually was at a time of labour shortage. Anti-foreigner sentiment before and after the outbreak of war clearly manifested itself, for instance in the debates noted above in local authorities as to whether to employ refugees. Sometimes, as in the case of Greenock, labour market concerns over-rode such sentiment; at other times, as in the case of Gateshead, they did not. Such popular hostility both reflected and caused official attitudes, especially in summer 1940 when complex, and sometimes contradictory, regulations disqualified various categories of refugee nurses from some or all employment. Czechoslovakian refugees, for example, had seen their country dismembered, in part due to British collusion, only to find themselves treated, albeit temporarily, as enemy aliens. The question of qualifications was also vexed, with the authorities firmly refusing to acknowledge the value of training outside the British Empire. The qualifications issue is further illuminated by the scheme for female refugee doctors to train and practice as midwives. In such episodes we can see a hierarchy of grades and status based on British exclusivity; the dominant attitude of nursing as a "caring" profession and therefore best done by women; and

\footnotetext{
${ }^{94}$ For a brief discussion of the historiographical debate as to how true this might have been of the refugee experience as a whole,
}

see Sherman, op. cit., note 2 above, 'Introduction to Second Edition'. 


\section{John Stewart}

an allegedly overstocked market for medical practitioners which, for women doctors, could be negotiated by accepting lower status work but within the feminine/caring paradigm..$^{95}$

That the refugee experience was complex can be seen in a letter sent by two German nurses, Marion Nachemstein and Ilse Held, to the Ministry of Labour in August 1940:

Dear Sir, We got your address from Sir W. Citrine, Trades Union Congress ... We have been one year in the Taunton and Somerset Hospital ... as Probationer Nurses. As we are German Jewish Refugees from the Nazi Oppression, we had to leave the Hospital, as it became a Military Hospital. We would be very much obliged to you if you could assist us, to find another employment as nurses. ${ }^{96}$

The distress of two Jewish refugees in being identified as "enemy aliens" and their dismissal from employment at a time when the defeat of Britain, and a subsequent invasion, seemed highly possible can only be imagined. On the other hand, these women were confident enough, and politically conscious enough, to seek the advice of a powerful figure in the British labour movement and Labour Party, Walter Citrine. Citrine in turn appears to have responded positively and to have identified the appropriate government department to which a further request for help might be made. And, the tensions of the time notwithstanding, there is no reason to believe that the two refugees were anything other than sincere in seeking to continue their nursing careers as did others in the same situation. Nurses Nachemstein and Held can certainly be seen as "victims" of the panicky official measures of summer 1940, but they were not, on the other hand, passive victims who accepted their appointed fate unreservedly. On the contrary, they actively sought to negotiate their way through a complex and potentially demoralizing set of circumstances. Their experience, and that of other refugee nurses, can thus be seen as exemplifying the description of refugee women formulated by Sibylle Quack: "Between sorrow and strength". ${ }^{77}$

\footnotetext{
${ }^{95}$ On the issue of "caring" in nursing, see Tom Olson, 'Ordered to care? Professionalization, gender and the language of training, 1915-37', in Rafferty, Robinson and Elkan (ed.), op. cit., note 5 above, pp. $150-63$.

${ }^{96}$ PRO LAB 8/93, letter from Marion

Nachemstein and Ilse Held to the International
}

Labour Department, Ministry of Labour, 12 Aug. 1940. This was replied to on 15 Aug. but no further details are to be found in this file.

${ }^{97}$ Quack, op. cit., note 3 above. 